\title{
Tidal regimes of temperate coasts and their influences on aerial exposure for intertidal organisms
}

\author{
Gerhard Randall Finke $^{1, *}$, Sergio A. Navarrete ${ }^{1,2}$, Francisco Bozinovic ${ }^{2}$ \\ ${ }^{1}$ Estación Costera de Investigaciones Marinas, and ${ }^{2}$ Center for Advanced Studies in Ecology and Biodiversity, \\ Departamento de Ecología, Facultad de Ciencias Biológicas, Pontificia Universidad Católica, Alameda 340, \\ Casilla 114-D, Santiago, Chile
}

\begin{abstract}
Thermal stress and desiccation are the main causes of the upper limit to the distribution of organisms on rocky shores. The timing of low tides plays a key role in determining the exposure of intertidal organisms to potentially stressful desiccation and thermal conditions, and has recently been suggested as pivotal in predicting the effects of global warming. Using data generated from tidal harmonics for evenly spaced stations of temperate latitude $\left(23\right.$ to $\left.50^{\circ}\right)$, we compare the amount of time exposed to low tide during summer middays along 7 different coastlines (East Australia, east and west coasts of North and South America, and the west coasts of southern Africa and northern Africa-western Europe) for 3 standardized tidal heights. Eastern Australia and western South America consistently showed the greatest amount of time exposed to low tides during summer middays at all 3 tidal heights. Some of the highest exposures were observed in western North America in the higher intertidal, but were among the lowest in the mid- and lower intertidal levels. The east coast of North America showed intermediate exposure in the high intertidal, but exposure was among the highest at mid- and lower tidal levels. Among the lowest exposure times were observed at the remaining 3 coasts at all 3 tidal levels. Therefore, predictions about the consequences of climate change on coastal organisms will vary across continents.
\end{abstract}

KEY WORDS: Air exposure · Climatic changes $\cdot$ Eastern Pacific $\cdot$ Rocky shores $\cdot$ Temperate zones • Tides

Resale or republication not permitted without written consent of the publisher

\section{INTRODUCTION}

According to predictions by the Intergovernmental Panel for Climate Change (IPCC), average global temperatures are expected to increase by as much as 3 to $6^{\circ} \mathrm{C}$ over the next 50 to $100 \mathrm{yr}$ (IPCC 2001). Since the local and geographic distributions of marine and terrestrial organisms are often determined by temperature, these possible increases have generated substantial concern among ecologists, who have generated a body of empirical data, theory and models predicting major rearrangements of the world's biota. In terrestrial and marine ecosystems, respective changes in air and surface water temperature over the last 50 to $100 \mathrm{yr}$ have been related to changes in the abundance and/or distribution of species, resulting in a model for the biogeographic effects of global warming that predicts a poleward shift in the distributions of organ- isms (Castilla et al. 1993, Lubchenco et al. 1993, Barry et al. 1995, Olive 1995, Southward et al. 1995, Viner et al. 1995, Parmesan 1996, Davis et al. 1998, Easterling et al. 2000, Beaugrand et al. 2002, Thompson et al. 2002, Burns et al. 2003, Chevaldonné \& Lejeusne 2003, Parmesan \& Yohe 2003, Root et al. 2003, Sax \& Gaines 2003).

Rocky intertidal systems around the world have frequently been used at the forefront of the production and testing of ecological theories due to their relative simplicity (Little \& Kitching 1996). By definition the rocky intertidal organisms spend a substantial amount of time exposed to terrestrial conditions during low tides (air vs. water, solar radiation, wind etc.) which have been shown to impose substantial physiological stresses on these organisms (Somero 2005, Helmuth et al. 2006). These stresses, while frequently sublethal (Hofmann \& Somero 1995, 1996, Somero 2002, 
Tomanek 2002), suggest that many of these species are living at, or at least very near, the edges of their physiological tolerances (Somero 2002, Stillman 2002, 2003). As a matter of fact, one of the classic paradigms of intertidal ecology is that the upper distributional limit of intertidal species is delimited by desiccation and thermal stress (Little \& Kitching 1996). Therefore, by spending substantial periods in and out of the water, one can expect that the consequences of global climate change would affect intertidal species through changes in both air and water temperature. Since the extreme temperatures perceived by intertidal organisms generally occur during low tides, increased temperature during periods of aerial exposure is assumed to have a great effect on the survival, reproduction and physiology of the post-larval phases of these organisms.

Improving our ability to predict the effects of climate change depends crucially on having good descriptions of how local environmental conditions, i.e. those perceived by the organisms, vary over large areas, and how they are modulated by global-scale atmosphericoceanographic changes (Hallett et al. 2004, Helmuth et al. 2006). Considering the early emphasis on desiccation and thermal stresses on intertidal organisms (Orton 1929, Underwood 1978, Little \& Kitching 1998, Somero 2005), the scarcity of quantitative data describing intertidal environments over large areas is surprising. In recent articles, Helmuth et al. (2002, 2006) have started to fill this gap, describing patterns of thermal stress in the rocky intertidal zone of the Pacific coast of North America (hereafter 'PNA'). Their results highlight the long overlooked importance of incorporating air temperature and tidal regime when predicting effects of global warming on the geographical boundaries of intertidal organisms. For instance, Helmuth et al. (2002) show that the geographic variation in tidal regimes along the PNA generates predictions about the effects of global change that contrast with those from models based on sea surface temperature (SST) alone. They show that by the time thermal conditions are harshest, in the afternoon, the majority of intertidal organisms are protected by a higher tide, and that due to geomorphological factors that affect tidal regimes, some localities have low tides in the afternoon. When forecasted into climate change scenarios, this complex mosaic of 'hot spots' and 'cold spots' can generate patterns of local extinction within species boundaries that are not envisioned by the simple range expansion-contraction models (Helmuth et al. 2006).

Here, we expand on the results of Helmuth et al. (2002) by quantitatively describing the physical system of intertidal organisms in a global context, which constitutes a critical first step towards exploring the effect of climate on ecological systems (Helmuth et al. 2006,
Gilman et al. 2006). We use the tidal regimes as a proxy for the thermal environment and the potential for thermal stress and desiccation by quantifying the exposure to terrestrial conditions during midday in summer at 34 harmonic stations on 7 different coasts. We discuss how the differences in the tidal regimes may affect the distributions of species in the face of potential global climate change.

\section{MATERIALS AND METHODS}

Tidal data were generated using the software Tides for Windows (v. 3.8, available from www.arachnoid.com/ tides/) for a total of 34 harmonic stations (Fig. 1) at temperate latitudes (between 23 and $50^{\circ}$ ) on 7 coasts: East Australia, east and west coasts of the North and South America, southwestern Africa and the west coast of northern Africa-western Europe, at $10 \mathrm{~min}$ intervals from 1985 to 2010. Between 4 and 6 sites (harmonic stations) were selected on each coast, except for western Africa, where we found reliable information for only 3 sites. Data for each station were scaled to a relative value representing the percent tidal height with the reference to the highest high and the lowest low for the station between 1980 and 2020. The harmonic stations were selected to be on the open coast and not inside large topographic embayments to allow comparisons among coasts.

Cumulative midday aerial exposure was calculated as the total time that heights of 75,50 and $25 \%$ of the total tidal range spend emersed throughout $90 \mathrm{~d}$ of summer beginning on the summer solstice of the corresponding hemisphere and year, $1 \mathrm{~h}$ before and $2 \mathrm{~h}$ after solar noon. Solar noon was calculated as the midpoint between daily sunrise and sunset data generated using Tides (v. 3.8). Solar radiation is at its daily maxima at solar noon and air temperature reaches the daily maxima approximately $1 \mathrm{~h}$ later. This $3 \mathrm{~h}$ window was therefore selected because it is the period when thermal conditions are harshest for marine organisms.

For a global analysis, and since some stations showed a strong lunar nodical signal in the cumulative midday aerial exposure, the mean of $18 \mathrm{yr}$ (1993 to 2010) was calculated for each station, from which regional means were calculated and tested via 2-way ANOVA with tidal height (3 levels) and coast ( 7 coasts) as fixed factors. Multiple post-hoc comparisons were conducted with Tukey HSD tests when appropriate.

\section{RESULTS}

Relative differences in aerial exposure among sites and among regions over the 25 yr window examined 


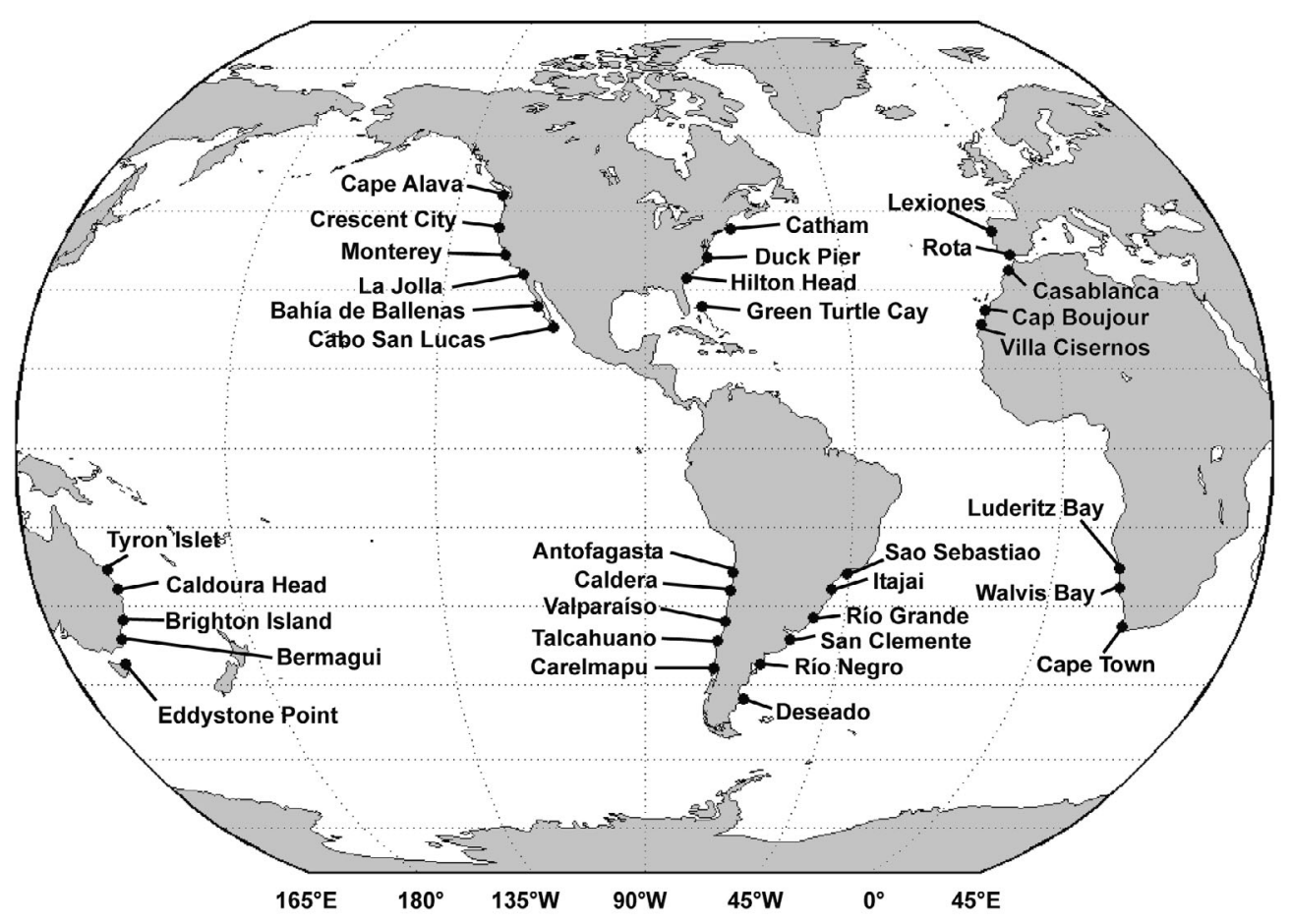

Fig. 1. Location of the 34 harmonic stations along 7 different coastlines

were highly persistent, despite the existence of an 18.6 yr lunar nodical cycle at some sites, especially in the northeastern Pacific (see Figs. A1 to A3 in Appendix 1, available as Supplementry Material online at www.int-res.com/articles/suppl/m343p057_app.pdf). Other smaller amplitude cycles of about 4 yr were also apparent at some sites and tidal heights, indicating that although the ranking of sites and regions does not change, the magnitude of the differences changes at a scale of a few years. Averaging over 18 yr makes results easier to interpret among sites. For a complete time series of the cumulative mid-summer day aerial exposure for the 3 tidal heights see Appendix 1 .

A significant interaction between region and tidal height was observed $\left(F_{(12,81)}=2.35, \mathrm{p}=0.0119\right)$, which is produced by differences in the shape of the tidal cycle in the different regions. Overall differences among regions were significant $\left(F_{(6,81)}=19.67, \mathrm{p}<\right.$ $0.001)$, but the significant interaction shows that relative aerial exposure among regions changes, depending on the tidal height occupied by the organism. In the high intertidal level ( $75 \%$ of the tidal range) average cumulative mid-summer day aerial exposure in all coasts ranged from 190 to $270 \mathrm{~h}$ (Fig. 2A) and a Tukey HSD test yielded 2 distinct groups. The first, consisting of the Southwestern Pacific (SWP), Southeastern Pacific (SEP) and Northeastern Pacific (NEP) was significantly greater than the second, consisting of the Southwestern Atlantic (SWA), Southeastern Atlantic
(SEA) and Northeastern Atlantic (NEA). The Northwestern Atlantic (NWA) coast was not different from either of the 2 groups.

At a height of $50 \%$ of the tidal range, average cumulative mid-summer day aerial exposure was substantially lower than in the higher intertidal, and the pattern of differences was slightly different (Fig. 2B). Tukey HSD tests showed that exposure along SWP was greater than all coasts SEP and NWA, and that exposure along SEP was greater than NEP. The remaining groups were not significantly different. Interestingly, NEP, which was among the most exposed in the high intertidal, showed the lowest exposure of all 7 regions in the mid-intertidal. In the low intertidal zone $(25 \%$ of the tidal range), cumulative day aerial exposure was lower and the overall pattern was similar to that observed in the mid-intertidal zone (Fig. 2C).

In summary, the cumulative mid-summer day exposure to air was highest in Eastern Australia (SWP) and in Chile (SEP). The NEP was grouped with the greatest exposure in the high intertidal zone, but with the lowest in the mid- and low intertidal zones.

\section{DISCUSSION}

A few studies have documented the effects of increases in SST on the geographical distributions of rocky intertidal organisms. For example, Barry et al. 

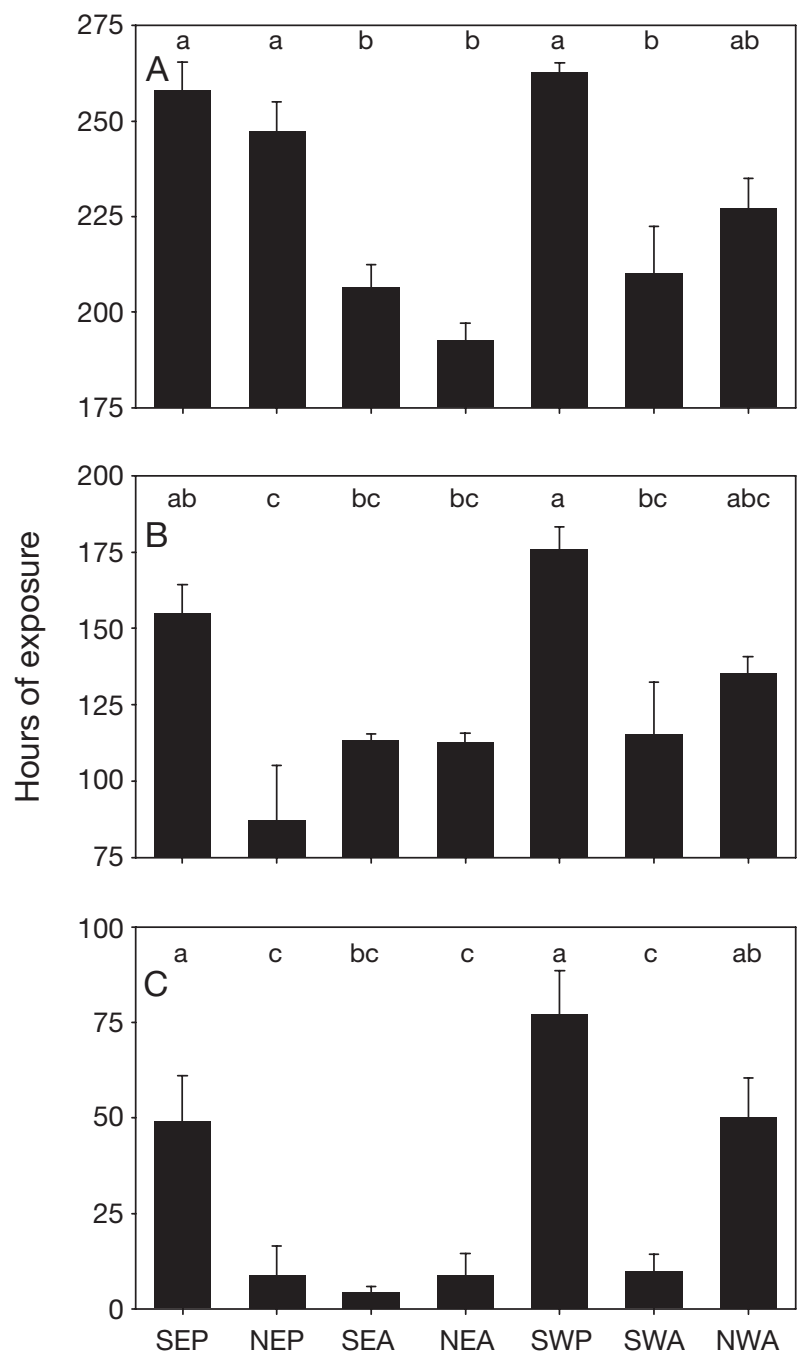

Fig. 2. Comparison of cumulative midday aerial exposure during summer for temperate latitudes on 7 coasts. (A) High intertidal ( $75 \%$ of tidal range), (B) mid-intertidal (50\% of tidal range), and (C) low intertidal (25\% of tidal range). SEP: Southeastern Pacific; NEP: Northeastern Pacific; SEA: Southeastern Atlantic; NEA: Northeastern Atlantic; SWP: Southwestern Pacific; SWA: Southwestern Atlantic; NWA: Northwestern Atlantic. Error bars: SE

(1995) and Sagarin et al. (1999) showed that between the 1930s and the 1990s, at Hopkins Marine Station in Central California, USA, a large percentage of species showed changes in abundance in accordance with poleward shifts in their ranges of distribution following an increase in SST. Similarly, Rivadeneira \& Fernández (2004) attributed minor changes in the southern endpoints of mollusk species distributions along the coast of Chile to changes in SST.

Since air temperatures in temperate locations can exceed SST by as much as $15^{\circ} \mathrm{C}$ or more (Helmuth 1998, 1999, Stillman \& Somero 2000, Finke 2007), and since physiological stresses are generally considered to be substantially higher during low tides, it stands to reason that the changes in the distribution and abundance of adult stages of intertidal organisms can be more affected by air temperature than changes in SST. Along these lines, Southward et al. (1995) documented marked changes in intertidal community structure at several sites in the western English Channel. They reported latitudinal shifts of up to 120 miles $(193 \mathrm{~km})$ and increases or decreases of up to 2-3 orders of magnitude in abundance of species in response to changes in mean global air temperature from the early 1920s to the 1990s.

The results of the present study show that in the midintertidal zones along the coasts of Chile and Eastern Australia, organisms spend 50 to $70 \%$ of summer afternoons exposed to terrestrial conditions. In comparison with sites on the open coast from the Pacific coast of North America (NEP), all Chilean and Australian stations showed 1.8 and 2.0 to 5.6 and 8.6 times greater cumulative midday aerial exposure, for low and midtidal heights, respectively. Considering only open coast sites, there is no evidence for 'hotspots' (Helmuth et al. 2002) along the Chilean coast, at least based on patterns of aerial exposure. Contrarily, exposure at Carelmapu in Chile was substantially lower than the rest of the SEP coast (see Appendix 1), suggesting it may be more of a 'coolspot' (sensu Helmuth et al. 2006). On the other hand, along eastern South America (SEA), the station at $33^{\circ}$ (Río Grande) showed substantially greater exposure in the mid- and high intertidal zones than the rest of the stations in the region, making it a 'hotspot'. Therefore, assuming relatively linear clines in air temperature and solar radiation with latitude, our results suggest that the potential effects of global warming through increased body temperatures during low tides will be substantially greater toward lower latitudes along the SEP and SWP. In situ measurements of microclimatic conditions experienced by model organisms (e.g. Gilman et al. 2006, Helmuth et al. 2006) are the logical next step to refine these broad predictions. A $5 \mathrm{yr}$ hindcast of modeled body temperatures of the intertidal mussel Perumytilus purpuratus in central Chile show that individuals reach body temperatures $>35^{\circ} \mathrm{C}$ on a regular basis, with average monthly maxima of $34^{\circ} \mathrm{C}$ each summer (Finke 2007). These results suggest that the high predicted aerial exposure in this region during periods of peak solar radiation does result in stressful conditions for the organisms.

The exposures in Australia and Chile were among the highest out of the 7 regions studied at all 3 tidal heights. The east coast of Australia consistently presented the greatest exposure. Interestingly, the exposure in the SWA was consistently among the lowest. Bertness et al. (2006) suggested that the coast of 
Patagonia, southern Argentina, is where the greatest desiccation stress in the intertidal zone occurs. These authors based their conclusion on meteorological data, but apparently did not take the tidal regime into account. Although we show that the SWA presents lower cumulative mid-summer day exposure to air than many other regions, this does not entirely contradict the findings of Bertness et al. (2006). Their conclusion was based on the effect of the strong dry winds coming off the South American mainland, which, according to these authors, impose stringent desiccation stresses. These winds are not likely to be related to the tides and therefore conditions favoring desiccation appear to occur at periods outside the $3 \mathrm{~h} \mathrm{~d}^{-1}$ window chosen for comparison here, highlighting the need to directly quantify microclimatic conditions.

Increases in body temperature have been shown to increase the production of heat shock proteins (Hofmann \& Somero 1995, Feder \& Hofmann 1999, Halpin et al. 2004, Sorte \& Hofmann 2004), which may have adverse effects on the energy left over for the maintenance, growth or reproduction (Hofmann \& Somero 1995, Feder \& Hofmann 1999). We predict that species inhabiting the Chilean and eastern Australian coasts should be more resistant to heat stress and or present marked physiological or behavioral adaptations. Moreover, for a given species and tidal height, heat shock protein concentration should follow a latitudinal trend in Chile, but not the NEP. Finally, in contrast with the prediction for the NEP (Helmuth et al. 2002), one could expect a poleward shift in the geographic limits of Chilean and eastern Australian rocky intertidal species.

Acknowledgements. Financial support for this research was provided by the Andrew Mellon Foundation (to S.A.N.) and the Center for Advanced Studies in Ecology and Biodiversity (FONDAP-Fondecyt 15001-001) and a doctoral fellowship (to G.R.F.) from the Dirección de Investicación y Postgrado of the Pontificia Universidad Católica de Chile. S.A.N. acknowledges support from Fondecyt 1040787 while preparing the manuscript. This research is submitted in partial fulfillment of the requirements for a PhD in the Departmento de Ecología, Pontificia Universidad Católica de Chile.

\section{LITERATURE CITED}

Barry JP, Baxter CH, Sagarin RD, Gilman SE (1995) Climaterelated, long-term faunal changes in a California rocky intertidal community. Science 267:672-675

Beaugrand G, Reid PC, Ibañez F, Lindley JA, Edwards M (2002) Reorganization of north Atlantic marine copepod biodiversity and climate. Science 296:1692-1694

Bertness MD, Crain CM, Silliman BR, Bazterrica MC, Reyna MV, Hidalgo F, Farina JK (2006) The community structure of western Atlantic Patagonian rocky shores. Ecol Monogr 76:439-460

Burns CE, Johnston KM, Schmitz OJ (2003) Global climate change and mammalian species diversity in U.S. national parks. Proc Natl Acad Sci USA 100:11474-11477

Castilla JC, Navarrete SA, Lubchenco J (1993) Southeastern Pacific coastal environments: main features, large-scale perturbations, and global climate change. In: Mooney HA, Fuentes ER, Kronberg BI (eds) Earth system responses to global change: contrasts between North and South America. Academic Press, San Diego, CA

Chevaldonné P, Lejeusne C (2003) Regional warminginduced species shift in north-west mediterranean marine caves. Ecol Lett 6:371-379

Davis AJ, Lawton JH, Shorrocks B, Jenkinson LS (1998) Individualistic species responses invalidate simple physiological models of community dynamics under global environmental change. J Anim Ecol 67:600-612

Easterling DR, Meehl GA, Parmesan C, Changnon SA, Karl TR, Mearns LO (2000) Climate extremes: observations, modeling and impacts. Science 289:2068-2074

Feder ME, Hofmann GE (1999) Heat-shock proteins, molecular chaperones and the stress response: evolutionary and ecological physiology. Annu Rev Physiol 61:243-282

Finke GR (2007) Biofísica ecológica de invertebrados del intermareal rocoso: el rol del intercambio térmico y las fuerzas hidrodinamicas del oleaje. PhD dissertation, Pontificia Universidad Católica de Chile, Santiago

Gilman SE, Wethey DS, Helmuth B (2006) Variation in the sensitivity of organismal body temperature to climate change over local and geographic scales. Proc Natl Acad Sci USA 103:9560-9565

Hallett TB, Coulson T, Pilkington JG, Clutton-Brock TH, Pemberton JM, Grenfell BT (2004) Why large-scale climate indices seem to predict ecological processes better than local weather? Nature 430:71-75

Halpin PM, Menge BA, Hofmann GE (2004) Experimental demonstration of plasticity in the heat shock response of the intertidal mussel Mytilus californianus. Mar Ecol Prog Ser 276:137-145

Helmuth B (1998) Intertidal mussel microclimates: predicting the body temperature of a sessile invertebrate. Ecol Monogr 68:51-74

Helmuth B (1999) Thermal ecology of rocky intertidal mussels: quantifying body temperatures using climatological data. Ecology 80:15-34

Helmuth B, Broitman BR, Blanchette CA, Gilman S and 6 others (2006) Mosaic patterns of thermal stress in the rocky intertidal zone: implications for climate change. Ecol Monogr 76:451-479

Helmuth B, Harley CDG, Halpin PM, O'Donnell M, Hofmann GE, Blanchette CA (2002) Climate change and latitudinal patterns of intertidal thermal stress. Science 298: 1015-1017

Hofmann GE, Somero GN (1995) Evidence for protein damage at environmental temperatures: seasonal changes in levels of ubiquitin conjugates and hsp70 in the intertidal mussel Mytilus trossulus. J Exp Biol 198:1509-1518

Hofmann GE, Somero GN (1996) Protein ubiquitination and stress protein synthesis in Mytilus trossulus occurs during recovery from tidal emersion. Mol Mar Biol Biotechnol 5:175-184

IPCC (Intergovernmental Panel on Climate Change) (2001) Climate change 2001: the scientific basis. In: McCarthy JJ, Canziani OF, Leary NA, Dokken DJ, White KS (eds) Cambridge University Press, Cambridge

Little C, Kitching JA (1996) The biology of rocky shores. Oxford University Press, Oxford

Lubchenco J, Navarrete SA, Tissot BN, Castilla JC (1993) Possible ecological responses to global climate change: 
nearshore benthic biota of northeastern Pacific coastal ecosystems. In: Mooney HA, Fuentes ER, Kronberg BI (eds) Earth system responses to global climate change: contrasts between North and South America. Academic Press, San Diego, CA

Lutus P (2000) Tides. Computer program for Windows. Available at: http://www.arachnoid.com/tides/

Olive PJW (1995) Annual breeding cycles of marine invertebrates and environmental temperature: probing the proximate and ultimate causes of reproductive synchrony. J Therm Biol 20:79-90

Orton JH (1929) On the occurrence of Echinus esculentus on the foreshore in the British Isles. J Mar Biol Assoc UK 16:289-296

Parmesan C (1996) Climate and species' range. Nature 382:765-766

Parmesan C, Yohe G (2003) A globally coherent fingerprint of climate change impacts across natural systems. Nature 421:37-42

Rivadeneira MM, Fernandez M (2004) Shifts in southern endpoints of distribution in rocky intertidal species along the south-eastern Pacific coast. J Biogeogr 31:1-7

Root TL, Price JT, Hall KR, Schneider SH, Rosenzweie C, Pounds JA (2003) Fingerprints of global warming on wild animals and plants. Nature 421:57-60

Sagarin RD, Barry JP, Gilman SE, Baxter CH (1999) Climate related change in an intertidal community over short and long time scales. Ecol Monogr 69:465-490

Sax DF, Gaines SD (2003) Species diversity: from global decreases to local increases. Trends Ecol Evol 18:561-566

Somero GN (2002) Thermal physiology and vertical zonation of intertidal animals: optima, limits, and costs of living. Integr Comp Biol 42:780-789

Somero GN (2005) Linking biogeography to physiology: evo-

Editorial responsibility: Steven Morgan (Contributing Editor), Bodega Bay, California, USA lutionary and acclimatory adjustments of thermal limits. Frontiers Zool 2:1-9

Sorte CJB, Hofmann GE (2004) Changes in latitudes, changes in aptitudes: Nucella canaliculata (Mollusca: Gastropoda) is more stressed at its range edge. Mar Ecol Prog Ser 274:263-268

Southward AJ, Hawkins SJ, Burrows MT (1995) Seventy years' observations of changes in the distribution and abundance of zooplankton and intertidal organisms in the western English channel in relation to rising sea temperature. J Therm Biol 20:127-155

Stillman JH (2002) Causes and consequences of thermal tolerance limits in rocky intertidal porcelain crabs, genus Petrolisthes. Integr Comp Biol, 42:790-796

Stillman JH (2003) Acclimation capacity underlies susceptibility to climate change. Science 301:65

Stillman JH, Somero GN (2000) A comparative analysis of the upper thermal tolerance limits of eastern Pacific porcelain crabs, genus Petrolisthes: influences of latitude, vertical zonation, acclimation, and phylogeny. Physiol Biochem Zool 73:200-208

Thompson RC, Crowe TP, Hawkins SJ (2002) Rocky intertidal communities: past environmental changes, present status and predictions for the next 25 years. Environ Conserv 29:168-191

Tomanek L (2002) The heat-shock response: its variation, regulation and ecological importance in intertidal gastropods (genus Tegula). Integr Comp Biol 42:797-807

Underwood AJ (1978) A refutation of critical tidal levels as determinants of the structure of intertidal communities on British shores. J Exp Mar Biol Ecol 33:261-276

Viner D, Hulme M, Raper SCB (1995) Climate change scenarios for the assessments of the climate change on regional ecosystems. J Therm Biol 20:175-190

Submitted: May 7, 2006; Accepted: February 6, 2007

Proofs received from author(s): July 12, 2007 